\title{
PERBANDINGN TINGKAT KEPUASAN PASIEN BPJS DAN NON BPJS TERHADAP MUTU PELAYANAN KEPERAWATAN DI RUANG RAWAT INAP RSIA PERMATA HATI
}

\author{
Ni Wayan Juli Astuti ${ }^{1}$, Ni Nyoman Santi Tri Ulandari ${ }^{2}$, Ageng Abdi Putra ${ }^{3}$, \\ Ni Made Sumartyawati ${ }^{4}$ \\ 1,2,3,4) Sekolah Tinggi Ilmu kesehatan (STIKES) Mataram \\ santhi_rastika@yahoo.com
}

\section{INTISARI}

Latar Belakang Badan Penyelenggara Jaminan Kesehatan (BPJS) kesehatan adalah suatu badan hukum publik yang bertanggung jawab kepada presiden dan berfungsi untuk menyelenggarakan program jaminan kesehatan bagi seluruh penduduk Indonesia. Keberlangsungan BPJS tidak bisa lepas dari kepuasan masyarakat, adapun kepuasan yang di maksud adalah tingkat perasaan seseorang setelah membandingkan kinerja (hasil) yang dirasakan dibandingkan dengan harapan. Adapun indikator kepuasana dalah Responsivenes, Ralibility, Assurance, Emphaty, tangible, Tujuan dari penelitian ini adalah Mengetahui bagaimana perbandingan tingkat kepuasan pasien BPJS dan Non BPJS terkait Mutu pelayanan keperawatan

Metode Penelitian ini mengunakan rancangan deskritif komperatif dengan metode pendekatan croos sectional, teknik pengambilan sempel menggunakan purposive sampling, dengan jumlah 50 responden yaitu 25 responden BPJS dan 25 responden Non BPJS pengambilan data dengan mengunakan kuesioner.

Hasil Berdasarkan hasil penelitian diperoleh hasil tidak ada perbedaan tingkat kepuasan pasien BPJS dan Non BPJS terkait Mutu Pelayanan Keperawatan

Kesimpulan Dalam pemberian pelayanan keperawatan tidak boleh membeda-bedakan antara pembayaran BPJS dan Non BPJS.

Kata kunci : Tingkat kepuasan, pasien BPJS, Pasien Non BPJS, Pelayanan Keperawatan

\section{COMPARISON OF SATISFACTION LEVEL OF BPJS AND NON BPJS PATIENTS IN RELATION TO NURSING SERVICES IN INPATIONTS ROOM OF RSIA PERMATA HATI HOSPITAL}

\author{
Ni wayan juli Astuti ${ }^{1}$, Ni Nyoman Santi Tri Ulandari ${ }^{2}$, Ageng Abdi Putra ${ }^{3}$, \\ Ni Made Sumartywati ${ }^{4}$ \\ ${ }^{1,2,3,4}$ Sekolah Tinggi Ilmu kesehatan ( STIKES ) Mataram \\ yanjuli61@gmail.com
}

\begin{abstract}
BPJS for Health program is public legal entity that is directlyresponsible to president of the Republic of Indonesia. The function is to provide health insurance for Indonesia citizen. The sustainability of BPJS can not be separated from the public
\end{abstract}


satisfaction denoted by the comparison between public expiatioandtheperformance of BPJS with the indicators of responsiveness, reliability, assurance, empathy, and tangible. This research is aimed at determining the comparison satisfaction level of BPJS patients and Non BPJS patients in relation to ursing service.

This research is comparative study croos-sectional approach, the samples were selected through purposive sampling to get 50 respondents each groupof BPJS and Non-BPJS consists of 25 respondents.The data were collected through questionnaires.

Based on the mannwhitneystatistic test, there differences of satisfaction level of BPJS patients and Non-BPJS patients in relation to quality of nursing service.Actually, nursing service should not be distinguished for the payment method between BPJS and Non BPJS patients

Keywords : Satisfaction Level, BPJS Patients, Non Patients BPJS, Nursing Services

\section{PENDAHULUAN}

Pembangunan kesehatan adalah investasi utama bagi pembangunan sumber daya manusia Indonesia. Pembangunan kesehatan pada dasarnya adalah upaya untuk meningkatkan kesadaran, kemauan, serta kemampuan setiap orang untuk dapat berperilaku hidup yang sehat untuk mencapai derajat kesehatan masyarakat yang setinggi-tingginya. Untuk mewujudkan hal tersebut, perlu perencanaan pembangunan kesehatan yang sistematis, terarah, terpadu dan menyeluruh, serta membutuhkan keterlibatan berbagai sektor dan seluruh komponen bangsa dalam pelaksanaannya.

Rumah Sakit Ibu dan Anak Permata Hati Mataram menjalin kerja sama pada tanggal 1 Januari 2017 dengan BPJS karena RSIA Permata Hati bergabung dengan BPJS maka pihak permata hati harus mengikuti peraturan yang dibuat oleh BPJS agar bisa di klem BPJS, RSIA Permata hati mataram adalah tipe rumah sakit " $\mathrm{C}$ " Khusus RSIA Permata Hati berfokus pada layamam Obsetri dan genekologi kesehatan anak dan neonatus terkait, dengan peraturan pihak BPJS bila pasien harus di rujuk kerumah sakit, maka rumah sakit yang pertama kali dituju adalah rumah sakit tipe $\mathrm{C}$ sebelum ke rumah sakit tipe B atau A maka RSIA permata Hati banyak mengalami peningkatan pasien BPJS hal tersebut bisa dilihat dari jumlah pasien partus rata-rata satu bulan sebanyak 192 pasien dengan rata-rata pasien partus normal sebanyak 69 pasien setiap bulan dan pasien oprasi sesar rata rata adalah 125 pasien setiap bulan sedangkan BOR(Bed Ocopancy Rate) yang menggunaan 44 tempet tidur yaitu rata rata satiap bulannya $81 \%$, pasien yang menggunakan cara pembayaran untuk BPJS rata-rata 219 pasien setiap bulan sedangkan yang Non BPJS 49 pasien setiap bulannya.

RSIA permata hati sebelumnya hanya menerima cara pembayaran Non BPJS. Setelah bergabung dengan BPJS terdapat beberapa perbedaan fasilitas yang diberikan, Perbedaan tersebut contohnya sebelum bergabung dengan BPJS pihak rumah sakit menyedikan perlengkapan bayi sehingga pasien tidak perlu membawa perlengkapan bayi sendiri, sedangkan setelah bekerjasama dengan pihak BPJS pasien BPJS dan Non BPJS harus membawa perlengkapan bayi sendiri.

Untuk pasien BPJS yang ingin mengambil kelas perawatan lebih tinggi dari kelas BPJS sesuai yang terdaftar, pihak RSIA Permata Hati menanyakan apakah pasien ingin mengganti obat 
yang tertanggung oleh BPJS dengan obat paten.

\section{METODE PENELITIAN}

Subyek pada penelitian ini adalah Pasien rawat inap di RSIA permata Hati Post Sectio Cesarea (SC). Populasi adalah keseluruhan subyek penelitian atau obyek yang diteliti (Notoatmodjo, 2010) Populasi dalam penelitian ini adalah semua pasien rawat inap Post SC dengan jaminan pembayaran BPJS dan non BPJS di ruang Ranap RSIA Permata Hati Mataram sebanyak 50 pasien.

Penelitian ini dalam pelaksanaannya berdasarkan prosedur yang telah di rencanakan, Desain penelitian dalam penelitian ini adalah suatu rencana yang bisa digunakan sebagai petunjuk dalam merencanakan dan melaksanakan penelitian untuk mencapai tujuan atau menjawab pertanyaan penelitian (Nursalam, 2011).

Desain penelitian yang akan digunakan oleh penelitian ini adalah deskritif komparatif dengan metode pendekatan cross sectional rencana penelitian yang pengukuran dan pengamatannya dilakukan secara stimultan pada suatu saat (sekali waktu).

Instrumen penelitin merupakan alat alat yang digunakan untuk mengumpulkan data (Notoatmodjo, 2012). Adapun instrumen yang digunakan adalah kuesioner yang telah dilakukan uji validitas dan reliabilitas. Lembar kuesioner terdiri dari 3 bagian yaitu data demografi, data pelayanan keperawatan, dan data kepuasan pasien. Berikut penjelesan dari 3 bagian.

\section{HASIL}

Tabel. 1. Karakteristik Responden

\begin{tabular}{clcc}
\hline No & \multicolumn{1}{c}{ Variabel } & Jumlah & $(\%)$ \\
& Umur & 14 & 28
\end{tabular}

\begin{tabular}{clcc} 
& 26-35 Tahun & 33 & 66 \\
& 36-45 Tahun & 3 & 6 \\
\hline 2 & Pekerjaan & & \\
\hline & Pegawai swasta & 23 & 46 \\
& Mahasiswa & 1 & 2 \\
& Pegawai negeri & 11 & 22 \\
& Ibu rumah tangga & 15 & 30 \\
\hline 3 & Pendidikan & & \\
\hline \multirow{2}{*}{ SD } & 4 & 8 \\
& SMP & 6 & 12 \\
& SMA & 17 & 34 \\
& D3 & 7 & 14 \\
D4/S1 & 15 & 30 \\
S2 & 1 & 2 \\
Jumlah & 50 & 100
\end{tabular}

Dari Tabel 1 di atas didapatkan bahwa usia terbanyak responden adalah usia 26-35 tahun yaitu 33 responden (66\%), dan dengan pekerjaan sangat bervariasi jumlah pekerjaan terbanyak responden adalah pegawai swasta sebanyak 23 responden (46\%). Serta didapatkan bahwa pendidikan responden terbanyak adalah berpendidikn SMA 17 responden $(34 \%)$.

Tabel 2. Perbandingan tingkat kepuasan pasien BPJS dan Non BPJS

\begin{tabular}{|c|c|c|c|c|c|c|c|}
\hline \multirow{2}{*}{$\begin{array}{l}\text { Tingkat } \\
\text { Kepuasan }\end{array}$} & \multicolumn{4}{|c|}{ Jenis Pelayanan } & \multirow[b]{2}{*}{ Total } & \multirow[b]{2}{*}{$\%$} & \multirow[b]{2}{*}{$\begin{array}{c}p \\
\text { value }\end{array}$} \\
\hline & BPJS & $\%$ & $\begin{array}{l}\text { Non } \\
\text { BPJS }\end{array}$ & $\%$ & & & \\
\hline $\begin{array}{l}\text { Sangat } \\
\text { Puas }\end{array}$ & 17 & 68 & 18 & 72 & 35 & 70 & 0.311 \\
\hline $\begin{array}{l}\text { Cukup } \\
\text { Puas }\end{array}$ & 5 & 20 & 5 & 20 & 10 & 20 & \\
\hline \multirow{2}{*}{$\begin{array}{l}\text { Kurang } \\
\text { Puas }\end{array}$} & 3 & 12 & 2 & 8 & 5 & 10 & \\
\hline & 25 & 100 & 25 & 100 & 50 & 100 & \\
\hline
\end{tabular}

Dari tabel di atas dapat dilihat bahwa jumlah responden yang menggunakan BPJS sebanyak 17 responden dan 18 responden tidak menggunakan BPJS. Hasil analisis dengan menggunakan uji Mann whitney di dapatkan hasil $p$ value $>0,05$. Hal ini menunjukkan bahwa tidak ada perbandingan yang signifikan pada tingkat kepuasan pasien BPJS dan Non BPJS di Ruang Rawat Inap RSIA Permata Hati. 


\section{PEMBAHASAN}

\section{Karakteristik Responden}

A. Usia

Menurut (Darwati, 2018) menyatakan bahwa pada usia 26-35 tahun banyak menyatakan puas terhadap pelayanan hal ini dikarenakan oleh pola pikir usia dewasa awal lebih matang untuk menilai puas tidaknya terhadap pelayanan. Hal ini juga sejalan dengan Lestiyani 2011 yang mengemukakan bahwa beberapa karakteristik indivindu yang menjadi penentu kualitas pelayanan kesehatan dan tingkat kepuasan pada pelanggan eksternal (pasien) adalah umur, lama perawatan, sumber biaya dan lainnya.

\section{B. Pekerjaan}

jenis pekerjaan seseorang menentukan tingkat harga diri dan keinginan untuk mendapatkan pelayanan yang baik. Hal ini dijelaskan oleh Haerani (2012) bahwa pola pikir dan cara menilai sesuatu dipengaruhi oleh faktor eksternal seperti lingkungan, teman sejawat, iklim kerja, pimpinan dan IPTEK. Dalam penelitian ini, responden terbanyak dari responden Non BPJS, responden merasa memiliki penghasilan sendiri dan jabatan, sehingga akan berimplikasi pada tuntutan pelayanan kesehatan yang baik.

C. Pendidikan

Semakin tinggi pendidikan seseorang semakin baik kualitas intelektual yang dimiliki, kemampuan analisis rasional dengan pertimbangan benar atau salah mengandalkan logika dan perasaan (Haerani, 2012). Pengetahuan tersebut mempengaruhi kemampuan pasien untuk mengetahui informasi tentang penyakitnya, kondisi serta perawatan yang diterimanya (Depkes RI, 2008).

Pada analisa data dari hasil penelitian yang telah dilakukan tentang perbandingan tingkat kepuasan pasien BPJS dan non BPJS yang telah dilakukan menunjukkan bahwa tidak terdapat perbandingan yang signifikan pada tingkat kepuasan pasien BPJS dan non BPJS, dengan taraf signifikan $p=0.311$ atau $p>0.05$.

Hal ini sejalan dengan penelitian yang dilakukan oleh Ramadhan (2015) menyatakan bahwa tidak terdapat perbedaan kepuasan pasien peserta BPJS Kesehatan dan pasien Umum terhadap pelayanan di Rumah Sakit Umum Negara 2015 dengan $p>0.05$.

Penggunaan BPJS Kesehatan hanya membedakan kelas pelayan dan perawatan yang diterima, namun tidak membedakan kualitas pelayanan dari segi resposivnes, reliability, assurance, emphaty dan tangible. Pasien BPJS tetap berhak menerima manfaat jaminan preventif, kuratif dan rehabilitative termasuk pelayanan obat dan bahan medis habis pakai sesuai dengan kebutuhan medis yang diperlukan tanpa terikat dengan besaran iuran (Susi, 2015).

Menurut Fry bahwa salah satu prinsip dasar etika keperawatan yaitu justice (keadilan) yang bermakna dalam praktek profesional ketika perawat bekerja untuk terapi yang benar sesuai hukum, standar praktik dan keyakinan yang benar untuk memperoleh kualitas pelayanan kesehatan.Setiap perawat harus memmperlakukan pasiennya dengan profesional sesuai dengan ilmu keperawatan, tanpa memandang status dan latar belakang pasien (Gusti, 2015). 


\section{SIMPULAN}

Tidak terdapat berbedaan pelayan Keperawatan BPJS dan Non BPJS di rawat Inap RSIA Permata Hati Matram

\section{DAFTAR PUSTAKA}

Departemen Kesehatan Repubik Indonesia 2008. Peran dan Fungsi Perawat dalam Peleyanan Kesehatan. Jakarta. Depkes RI.

Gusti. 2015. 8 Prinsip Etika Dalam Keperawatan. https://gustinerz.com/8-prinsipetika-dalam-keperawatan/. Diakses 1 Januari 2019.

Lestiyani, Pratidina. (2011). Mutu Pelayanan-Kepuasan Pelanggan. https://pratidinalestiyani.wordpres s.com//. Diakses 1 januari 2019

Nursalam, (2011). Manajemen Keperawatan. Jakarta : Selemba Medika

Notoatmojo, Soekidjo, (2010). Metodelogi penelitian Kesehatan. Jakarta : Rieneka Cipta.

Notoatmojo, Soekidjo, (2012). Metodelogi penelitian Kesehatan. Jakarta : Rieneka Cipta.

Ramadhan, Naufal, (2015). Perbedaan kepuasan pasien BPJS dan Pasien umum terhadap pelayanan kesehatan di Rumah Sakit Umum Negara. Tesis. Universitas Muhamadiyah Yogyakarta. Yogyakarta.

Susi, (2014) . pengertian, Dasar Hukum, Kepesertaan dan manfaat BPJS kesehatan.

Dinkes.Lumajangkab.go.id. diakses 5 Januari 2019 